Gelanggang Olahraga: Jurnal Pendidikan Jasmani dan Olahraga

Volume 1, Nomor 2, Januari-Juni 2018

e-ISSN : 2597-6567

p-ISSN : 2614-607X

DOI : https://doi.org/10.31539/jpjo.v1i2.156

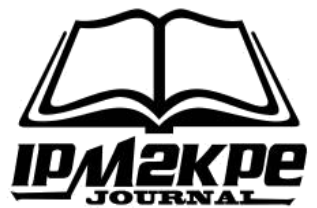

\title{
PENGARUH KEMAMPUAN KOGNITIF TERHADAP HASIL PEMBELAJARAN BOLA BASKET
}

\author{
Mirza Awali \\ Universitas PGRI Palembang \\ mirza.awali@gmail.com
}

\begin{abstract}
ABSTRAK
Metode yang digunakan dalam penelitian ini adalah metode eksperimen dengan desain two group pretest-postest. Populasi dalam penelitian ini adalah siswa putra kelas XI SMA Negeri 2 Lahat sebanyak 20 siswa. Teknik pengambilan sampel menggunakan teknik Sampling Jenuh, sebanyak 20 siswa dengan rincian 10 siswa kelompok kognitif tinggi dan 10 siswa kelompok kognitif rendah. Waktu penelitian yaitu selama 1 bulan, jumlah latihan 12 kali pertemuan, dengan frekuensi 1 minggu 3 kali. Instrumen yang dipilih penulis adalah tes intelegensi (IQ) untuk siswa sekolah menengah atas (untuk menentukan tingkat intelegensi) dan untuk keterampilan bolabasket (tes awal dan akhir keterampilan bolabasket) ada tiga tes dengan tingkat $r$ validitasnya 0,89 yaitu tes melempar dan menangkap bola, tes menembakkan bola ke keranjang dan tes menggiring bola.
\end{abstract}

Kata Kunci: Kemampuan Kognitif, Hasil Pembelajaran Bola Basket.

\section{ABSTRACT}

The method used in this research is the experimental method with two group pretest-postest designs. The population of this research are 20 male students of XI grade in SMA Negeri 2 Lahat. There are 20 students as the sample which are divided to 10 students in high cognitive group and the other 10 students in low cognitive group. This research takes 1 months, including 12 times meeting for exercise, with the frequency three times a week. The instrument that is choosen by the writer is intellegence test (IQ) for senior high school students (to determine the intellegency level) and for the basketball skill (first and last test of basketball skill), there are three test with the $r$ validity level is 0,89 that are throwing and catching ball, shooting ball into the basket, and dribbling ball test.

Keywords: Cognitive Ability, The Result of Basketball Learning

\section{PENDAHULUAN}

Bola basket merupakan salah satu olahraga yang paling popular di dunia. Olahraga ini sudah berkembang pesat sejak pertama kali diciptakan pada akhir abad ke-19. Penciptanya adalah Prof. Dr. James Naismith, dia merupakan seorang guru olahraga di YMCA (International Training School) yang kini berganti nama menjadi Springfield College. Mulanya ia menciptakan olahraga ini 
untuk membantu siswa agar tetap aktif dan bugar selama berbulan-bulan pada musim dingin di Masachusetts. Permainan bola basket merupakan permainan yang sangat menarik, selain mengandung aspek rekreatif, didalamnya juga terdapat unsur kerjasama dan kekompakan.

Sodikun (1991) menjelaskan "permainan bolabasket merupakan permainan yang gerakkannya kompleks yaitu gabungan dari jalan, lari, lompat, dan unsur kekuatan, kecepatan, kelentukkan dan lain-lain”. Dijelaskan pula mengenai karakteristik dalam permainan bolabasket oleh Sucipto (2010), "bahwa terdapat beberapa unsur yang tidak dapat dipisahkan yaitu menggiring bola sambil dipantulkan (dribbling), melempar (passing), menangkap (catching) dan menembak (shooting)."

Bola basket termasuk salah satu olahraga yang paling populer di dunia. Permainan bola basket selalu dipertandingkan antar mahasiswa, pelajar atau clubclub yang ada di Indonesia. Pada kalangan pelajar permainan bola basket cukup digemari dan diminati serta seringkali dipertandingkan antar kelas maupun antar sekolah. Di sekolah pun permainan bolabasket termasuk ke dalam salah satu bahan ajar dalam pendidikan jasmani yang terdapat dalam kurikulum pendidikan Nasional.

Permainan bola basket selain mengembangkan kegiatan bermain, juga mengembangkan aspek pembentukan kepribadian. Oleh karena itu, permainan bolabasket dapat dijadikan sarana untuk mengembangkan aspek fisik, mental emosional, dan intelektual para siswa. Hal ini sesuai dengan yang dijelaskan (Sucipto, 2010) bahwa "permainan bola basket bukan hanya mengembangkan aspek fisik saja, melainkan akan mengembangkan aspek kognitif, emosi, mental sosial, moral dan estetika". Tujuan yang ingin dicapai bersifat menyeluruh, mencakup domain psikomotor, kognitif, dan afektif.

Dalam dunia pendidikan proses pembelajaran permainan bola basket harus didukung oleh adanya metode pembelajaran yang dirancang dan dikondisikan mengarah kepada penguasaan gerak secara menyeluruh. Namun, untuk mengkondisikan hal tersebut perlu mengkaji berbagai hal seperti karakteristik gerak siswa, jumlah siswa, sarana dan prasarana yang tersedia, waktu pelajaran yang disediakan, serta metode pembelajaran yang sesuai dan mendukung terhadap proses pembelajaran.

Konsep pembelajaran menurut Sagala (2005) adalah suatu proses di mana lingkungan seseorang secara disengaja dikelola untuk memungkinkan ia turut serta dalam tingkah laku tertentu dalam kondisi-kondisi khusus atau menghasilkan respon terhadap situasi tertentu, pembelajaran merupakan subset khusus dari pendidikan. Sering dikatakan mengajar adalah mengorganisasikan aktivitas siswa dalam arti yang luas. Peranan guru bukan semata-mata memberikan informasi, melainkan juga mengarahkan dan memberi fasilitas belajar (directing and facilitating the learning) agar proses belajar lebih memadai. Pembelajaran mengandung arti setiap kegiatan yang dirancang untuk membantu seseorang mempelajari suatu kemampuan dan atau nilai yang baru. Proses pembelajaran pada awalnya meminta guru untuk mengetahui kemampuan dasar yang dimiliki oleh siswa meliputi kemampuan dasarnya, motivasinya, latar belakang akademisnya, latar belakang sosial ekonominya, dan lain sebagainya. Kesiapan guru untuk mengenal karakteristik siswa dalam pembelajaran merupakan modal utama penyampaian bahan belajar dan menjadi indikator suksesnya pelaksanaan 
pembelajaran. Sejalan dengan apa yang disampaikan Suciati, dkk (2007) bahwa "melalui kegiatan pembelajaran guru dapat membantu siswa mengembangkan kemandirian dan kepercayaan diri, kemampuan akademis dan rasa antusias untuk mengerjakan tugas-tugas selanjutnya, dalam suasana kelas yang memberi rasa aman kepada siswa." Untuk itu guru perlu mengenal tingkat kemampuan, minat dan latar belakang pengalaman siswa. Kemudian secara bertahap memberikan tugas atau latihan yang akan memberikan pengalaman keberhasilan kepada siswa sehingga mereka merasa mampu berhasil dalam tugas pelajarannya.

Pemilihan dan penggunaan metode pembelajaran yang tepat dalam proses pembelajaran praktek dengan tujuan agar hasil belajar keterampilan gerak dapat dikuasai dengan baik, merupakan upaya yang harus dilakukan oleh setiap pengajar. Untuk itu, perlu dikembangkan metode pembelajaran yang lebih efektif dan efisien, sesuai dengan tuntutan dan karakteristik siswa yang belajar. Karena hal tersebut salah satunya berhubungan dengan tingkat pemahaman dan kerumitan yang terkandung dalam permainan bolabasket itu sendiri. Artinya siswa yang memiliki tingkat kognitif dalam kategori rendah, akan mendapat kesulitan untuk mempelajarinya dan membutuhkan waktu yang lebih lama pada pencapaian hasil belajarnya karena terkendala oleh daya tangkap terhadap materi pembelajarannya.

Kemampuan kognitif bisa disebut juga dengan istilah inteligensi dan istilah intelegensi memiliki pengertian yang luas dan kompleks. Konsep para ahli tentang intelegensi itu berbeda-beda, perbedaan konsep ini terutama terletak dalam hal penekanan kepada aspek-aspek tertentu dari kemampuan mental yang dipandang sebagai kualitas perilaku yang inteligen. (Freeman, 1962) mengemukakan bahwa: "Intelligence is the aggregate or global capacity of the individual to act purposefully, to think rationally and to deal effectively with his environment." Atau inteligensi dipandang sebagai kemampuan umum pada diri individu untuk melakukan kegiatan bermakna, berpikir rasional, dan kemampuan menghadapi ligkungannya secara efektif.

Berdasarkan pernyataan di atas, pengajar harus dapat mensiasati atau mengatasi masalah tersebut, dengan tidak menggunakan atau memanfaatkan metode pembelajaran yang asal-asalan, artinya pengajar harus mampu merencanakan, menetapkan dan menerapkan berbagai upaya yang berhubungan dengan kegiatan belajar-mengajar, tentunya pemilihan metode pembelajaran sangatlah efektif untuk terciptanya hasil belajar yang diharapkan.

Pendidik harus memiliki strategi mengajar yang tepat dan disesuaikan dengan situasi, kondisi, dan tujuan pengajaran. Efektivitas proses belajar mengajar, menurut Sagala (2005) adalah "efektivitas mengajar ditandai oleh gurunya yang selalu aktif dan siswanya secara konsisten aktif belajar." Artinya dalam lingkungan pembelajaran yang efektif, siswa tidak bekerja sendiri melainkan selalu diawasi oleh gurunya dan mereka tidak banyak waktu yang terbuang begitu saja. Jalannya aktivitas belajar begitu aktif, sibuk, dan menantang bagi siswa akan tetapi masih berada diantara tingkat perkembangan dan kemampuan siswanya, yang pada akhirnya siswa dapat menerima pesan atau intruksi dari gurunya dengan baik dan dapat melakukan latihan secara independen mempelajari sesuatu sesuai dengan tujuan pembelajarannya.

Berdasarkan pengalaman dan pengamatan yang telah dilakukan sampai saat ini, baik dalam intrakurikuler maupun ekstrakulikuler, banyak guru pendidikan jasmani maupun pelatih di sekolah belum secara optimal melakukan proses 
belajar mengajar seperti yang diharapkan dalam upaya meningkatkan hasil belajar kemampuan bolabasket. Hal ini diantaranya terjadi karena karakteristik siswa yang berbeda-beda, seperti kemampuan kognitif, kondisi fisik, kompleksitas gerak permainan tersebut dan kurangnya pemahaman guru dalam penerapan metode pembelajaran.

Di samping itu, metode pembelajaran yang sering digunakan dalam pelaksanaan kegiatan belajar mengajar, salah satu diantaranya adalah metode pembelajaran langsung yang mayoritas digunakan oleh para pengajarnya. Metode pembelajaran langsung adalah suatu pemindahan pengetahuan dari guru kepada siswa secara langsung, misalnya melalui ceramah, demontrasi, dan tanya jawab yang melibatkan seluruh kelas. Metode pembelajaran ini berpusat pada guru, dimana guru menyampaikan isi akademik dalam format yang terstruktur, mengarahkan kegiatan para siswa, dan mempertahankan fokus pencapaian akademik.

Dalam penelitian ini penulis khususnya akan mengkaji permasalahan terkait kemampuan kognitif siswa, karena sesuai permasalahan yang dialami penulis bahwa hasil belajar kemampuan bolabasket siswa di SMA Negeri 2 Lahat tidak menunjukkan peningkatan yang signifikan secara keseluruhan. Artinya, hanya sebagian kecil dari keseluruhan siswa yang menunjukkan peningkatan berarti. Oleh karena itu, penulis ingin mencoba meneliti terkait "pengaruh kemampuan kognitif terhadap hasil pembelajaran bolabasket dalam pendidikan jasmani."

\section{KAJIAN TEORI \\ Kemampuan Kognitif}

Menurut Sujiono (2010) bahwa "Kemampuan kognitif adalah proses berpikir, seperti memecahkan masalah, membandingkan, mengevaluasi dan kreativitas. Selain itu, aspek kognitif meliputi fungsi intelektual seperti pemahaman, pengetahuan dan keterampilan berpikir." Sementara itu Darsinah (2011) menjelaskan bahwa Inteligensi adalah "kemampuan kognitif yang dimiliki organisme untuk menyesuaikan diri secara efektif pada lingkungan yang kompleks dan selalu berubah serta dipengaruhi oleh faktor genetik."

Berdasarkan beberapa pernyataan di atas, kemampuan kognitif bisa disebut juga dengan istilah inteligensi dan istilah intelegensi memiliki pengertian yang luas dan kompleks. Konsep para ahli tentang intelegensi itu berbeda-beda, perbedaan konsep ini terutama terletak dalam hal penekanan kepada aspek-aspek tertentu dari kemampuan mental yang dipandang sebagai kualitas perilaku yang inteligen.

\section{Alat Ukur Kemampuan Kognitif}

Kemampuan kognitif bisa disebut juga sebagai inteligensi atau kecerdasan. Untuk membedakan seseorang dengan individu lain adalah kecerdasannya. Menurut Prasetyo (2011) "untuk membedakan manusia dengan manusia lainnya adalah kecerdasan."

Menurut Hariwijaya (2005), bahwa Intelegence Quotient (IQ) adalah "nilai yang diperoleh dari sebuah alat tes kecerdasan." Hasil tes ini memberikan indikasi mengenai taraf kecerdasan seseorang dan menggambarkan secara hampir keseluruhan. Salah satu cara yang sering digunakan untuk menyatakan tinggi rendahnya tingkat intelegensi adalah menterjemahkan hasil tes intelegensi ke 
dalam angka yang dapat menjadi petunjuk mengenai kedudukan tingkat kecerdasan seseorang bila dibandingkan secara relatif terhadap suatu norma.

Dalam penelitian ini, tes yang digunakan untuk mengukur kemampuan kognitif merupakan tes yang sudah umum digunakan para ahli psikologi yang berupa pertanyaan-pertanyaan dengan pilihan ganda yang terdiri dari tes verbal, numerik dan ruang.

\section{Hakikat Permainan Bolabasket}

Permainan bolabasket merupakan permainan yang sangat menarik, selain mengandung aspek rekreatif, didalamnya juga terdapat unsur kerjasama dan kekompakan. Permainan ini dapat dimainkan oleh siapa saja putra maupun putri dan tidak adanya batasan golongan, baik itu dari golongan kaya ataupun miskin. Menurut Sucipto (2010), permainan bolabasket adalah "permainan yang dimainkan dengan tangan, dalam arti bola selalu dimainkan dari tangan ke tangan pemain dalam satu regu." Bolabasket memiliki gerakan yang lengkap (komplek), seperti gerakan kaki pada saat berlari dan gerakan tangan pada saat menggiring bola, mengumpan bola, menangkap dan menembak ke keranjang lawan.

Sodikun (1991) menjelaskan "Permainan bolabasket merupakan permainan yang gerakkannya kompleks yaitu gabungan dari jalan, lari, lompat, dan unsur kekuatan, kecepatan, kelentukkan dan lain-lain". Dijelaskan pula mengenai karakteristik dalam permainan bolabasket oleh Sucipto (2010), "bahwa terdapat beberapa unsur yang tidak dapat dipisahkan yaitu menggiring bola sambil dipantulkan (dribbling), melempar (passing), menangkap (catching) dan menembak (shooting)."

Berdasarkan beberapa pendapat ahli di atas, dapat diasumsikan bahwa permainan bolabasket itu cukup komplek baik dari cara bermain, gerakan, dan peraturannya. Oleh karena itu, bila dikaitkan dengan pembelajaran bolabasket dan karakteristik para siswa yang berbeda-beda, misalnya mengenai kebugaran jasmani, kemampuan motorik, dan sebagainya merupakan hal-hal yang sering ditemui dilapangan dalam proses belajar mengajar pendidikan jasmani. Dengan demikian, sudah tentunya guru atau pengajar harus mampu mensiasati masalah tersebut, salah satunya dengan pemilihan model pembelajaran yang tepat sehingga tujuan pembelajaran yang diharapkan dapat tercapai secara optimal.

\section{METODE PENELITIAN}

Penelitian adalah salah satu cara dalam mencari suatu kebenaran melalui cara-cara ilmiah atau metode ilmiah. Metode ilmiah itu, berarti kegiatan penelitian yang didasarkan pada ciri-ciri keilmuan. Menurut Sugiyono (2010) menyatakan ciri-ciri keilmuan sebagai berikut, yaitu rasional, empiris, dan sistematis. Rasional berarti kegiatan penelitian itu dilakukan dengan cara-cara yang masuk akal, sehingga terjangkau oleh penalaran manusia. Empiris berarti cara-cara yang dilakukan itu dapat diamati oleh indera manusia, sehingga orang lain dapat mengetahui dan mengamati cara-cara yang digunakan. Sistematis artinya, proses yang digunakan dalam penelitian itu menggunakan langkahlangkah tertentu yang bersifat logis.

Metode penelitian yang digunakan dalam penelitian ini adalah metode eksperimen. Metode ini digunakan atas dasar pertimbangan bahwa sifat penelitian eksperimental yaitu mencobakan sesuatu untuk mengetahui pengaruh atau akibat 
dari suatu perlakuan atau treatment. Disamping itu penulis ingin mengetahui pengaruh variabel bebas terhadap variabel terikat yang diselidiki atau diamati mengenai metode eksperimen ini.

Hal ini selaras dengan permasalahan penulis yang ingin mengetahui hubungan sebab akibat dari pengaruh metode pembelajaran langsung pada siswa kognitif tinggi dan rendah terhadap hasil belajar keterampilan bolabasket. Varibel-variabel dalam penelitian ini terdiri atas dua variabel bebas, yaitu metode pembelajaran langsung (variabel bebas aktif) dan kognitif tinggi dan rendah (variabel bebas atribut). Adapun variabel terikat dalam penelitian ini adalah hasil belajar keterampilan bola basket.

Populasi dan sampel merupakan bagian yang penting dari sebuah penelitian. Ketelitian dalam menentukan sampel dari sejumlah populasi sangat menentukan hasil penelitian yang dilakukan. Populasi merupakan individu atau objek yang memiliki sifat-sifat umum. Dari populasi dapat diambil sejumlah data yang diperlukan untuk memecahkan suatu masalah yang diteliti. Sugiyono (2010) menjelaskan sebagai berikut "Populasi adalah wilayah generalisasi yang terdiri atas obyek/subyek yang mempunyai kualitas dan karakteristik tertentu yang ditetapkan oleh peneliti untuk dipelajari dan kemudian ditarik kesimpulannya." Jadi populasi bukan hanya orang, tetapi juga obyek dan benda-benda alam yang lain. Populasi juga bukan sekedar jumlah yang ada pada obyek atau subyek yang dipelajari, tetapi meliputi seluruh karakteristik atau sifat yang dimiliki oleh subyek atau obyek itu. Populasi yang penulis gunakan dalam penelitian ini adalah siswa putra kelas XI SMA Negeri 2 Lahat sebanyak 20 siswa. Teknik pengambilan sampel menggunakan teknik Sampling Jenuh, sebanyak 20 siswa dengan rincian 10 siswa kelompok kognitif tinggi dan 10 siswa kelompok kognitif rendah. Waktu penelitian yaitu selama 1 bulan, jumlah latihan 12 kali pertemuan, dengan frekuensi 1 minggu 3 kali.

Desain penelitian merupakan rancangan tentang cara menyimpulkan dan menganalisis data agar dapat dilaksankan secara ekonomis dan sesuai dengan tujuan penelitian. Desain penelitian adalah suatu rancangan percobaan (dengan tiap langkah tindakan yang betul-betul teridentifikasikan) sedemikian rupa sehingga informasi yang berhubungan atau diperlukan untuk persoalan yang sedang diselidiki dapat dikumpulkan.

Desain penelitian ini terdiri dari dua variabel bebas dan satu variabel terikat. Variabel bebas adalah variabel yang mempengaruhi dan sebagai penyebab salah satu faktor dalam penelitian. Sedangkan variabel terikat adalah variabel yang dipengaruhi.

Desain penelitian yang akan penulis gunakan adalah two group pretestposttest design dengan dua subyek penelitian pertama-tama melakukan pretest atau tes awal, kemudian diberikan perlakuan sesuai waktu yang ditentukan dengan metode yang penulis gunakan yaitu metode eksperimen, lalu melakukan posttest atau tes akhir.

\section{Instrumen Penelitian}

Instrumen penelitian adalah alat atau tes yang digunakan untuk mengumpulkan data. Untuk menentukan kemampuan kognitif siswa, peneliti menggunakan tes intelegensi untuk siswa sekolah menengah atas. Sedangkan untuk tes keterampilan bolabasket, tes yang akan digunakan dalam penelitian ini 
terdiri dari tiga tes dengan tingkat $\mathrm{r}$ validitasnya 0,89 yang diperoleh dan hasil penghitungan multiple korelasi dengan metode Werry-Doelittle, dalam Nurhasan (2001) yaitu tes melempar dan menangkap bola, tes menembakkan bola ke dalam keranjang, tes menggiring bola. Tes keterampilan bolabasket ini dapat digunakan untuk mengklasifikasikan kemampuan para siswa, menentukan kemajuan hasil belajar siswa, dan mengetahui hasil belajar siswa dan kemampuan siswa dalam cabang olahraga bola basket. Untuk lebih jelasnya, mengenai tes kemampuan bola basket sebagai berikut:

\section{Tes melempar dan menangkap bola}

Orang coba dengan bola di tangan, berdiri di belakang garis yang jauhnya 3 meter dari tembok. Setelah aba-aba "ya", testee berusaha melemparkan bola dalam waktu 30 detik. Selama melakukan tes, testee tidak boleh menginjak atau melewati garis. Apabila pada waktu melakukan lemparan, salah satu atau kedua kaki testee menginjak atau melewati garis, maka lemparan tersebut dianggap tidak sah dan tidak diberi angka. Lemparan dihitung sejak bola lepas dari kedua tangan.

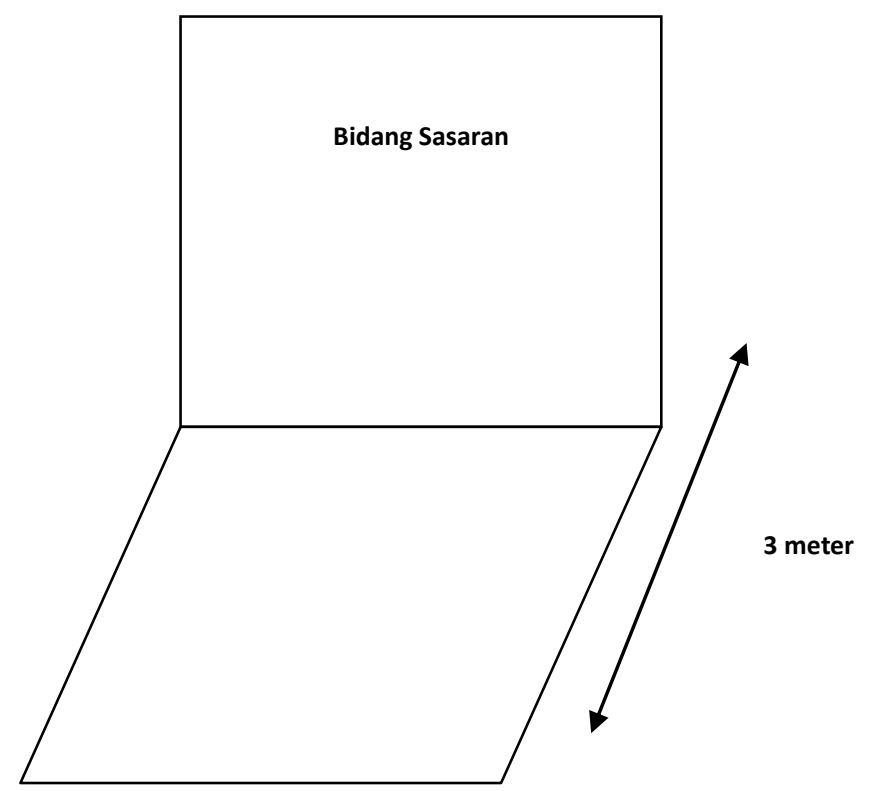

Gambar 1.Diagram Lapangan Tes Melempar dan Menangkap Bola

\section{Tes menembakkan bola ke keranjang basket}

Orang coba dengan bola di depan dada, berdiri disembarang tempat di bawah basket. Setelah aba-aba "ya", testee berusaha memasukkan bola tersebut sebanyak mungkin ke dalam basket dalam waktu 30 detik. Sebelum masuk ke dalam keranjang basket, bola harus terlebih dahulu menyentuh papan basket. Hanya bola yang sah masuk diberi skor. 


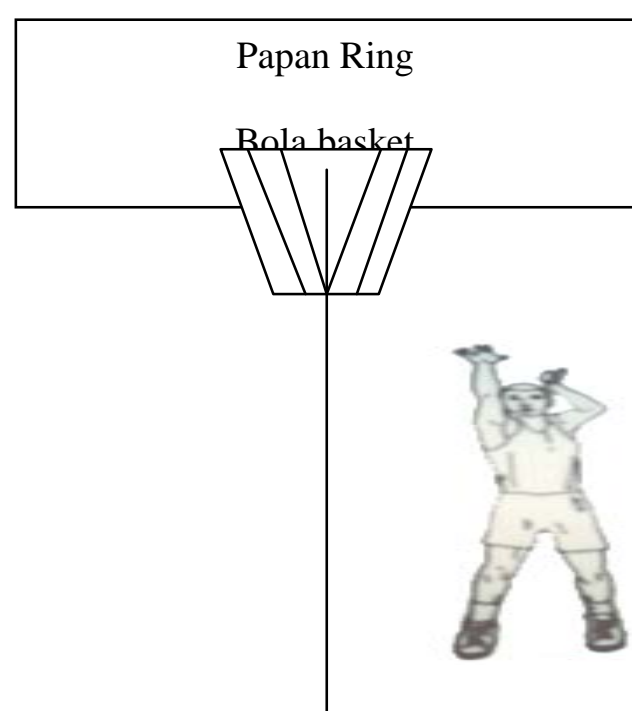

Gambar 2. Tes Menembakkan Bola Ke Keranjang

\section{Tes menggiring bola}

Sebelum melakukan tes, testee berdiri dengan bola di belakang garis start. Setelah aba-aba "ya", testee menggiring bola melalui enam rintangan sebanyak mungkin. Apabila setelah testee mencapai titik start kembali waktu 30 detik belum selesai, maka testee melanjutkan menggiring bola dengan rute seperti semula. Skor ditentukan oleh jumlah rintangan yang mampu dilalui testee. Apabila testee melakukan salah menggiring atau melalui rute yang salah, maka tes harus diulangi.

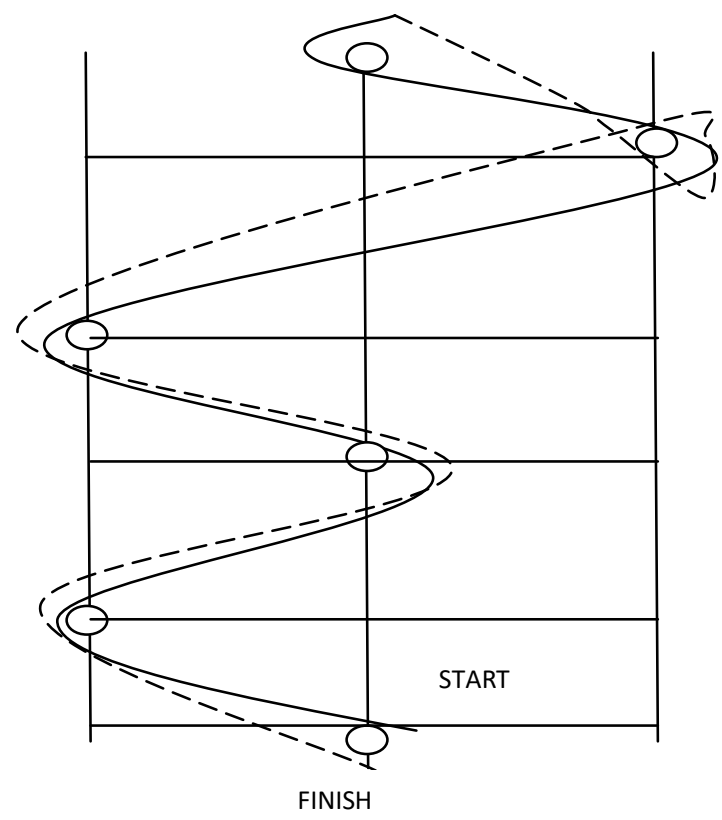

Gambar 3.Tes Menggiring Bola 


\section{HASIL PENELITIAN}

\section{Deskripsi Data}

Deskripsi data merupakan gambaran umum mengenai masing-masing variabel sebagai pendukung dalam pembahasan berikutnya. Melalui gambaran umum ini akan tampak kondisi awal dan setelah dilaksanakan perlakuan dari variabel yang diteliti.

Berdasarkan data hasil belajar kemampuan bola basket, diperoleh dari hasil tes keterampilan bolabasket, yaitu passing, shooting dan dribbling. Data yang digunakan untuk di analisis adalah dari hasil pre-test dan post-test selesai mengikuti proses pembelajaran yang menggunakan metode pembelajaran langsung terkait dengan kelompok yang memiliki IQ tinggi dan rendah. Rangkuman mengenai deskripsi data keterampilan bolabasket dapat dilihat pada Tabel 1.

Tabel 1

Deskripsi Data Hasil Pembelajaran Bolabasket

\begin{tabular}{ccccccc}
\hline \multirow{2}{*}{ Kelompok } & \multicolumn{2}{c}{ Tes Awal } & \multicolumn{2}{c}{ Tes } & \multicolumn{2}{c}{ Selisih } \\
\cline { 2 - 7 } & $\ddot{\mathbf{X}}$ & sd & $\ddot{\mathbf{X}}$ & sd & $\ddot{\mathbf{X}}$ & sd \\
\hline $\begin{array}{c}\text { Kognitif } \\
\text { Tinggi }\end{array}$ & 34.2 & 3.01 & 53.4 & 5.67 & 19.2 & 2.66 \\
$\begin{array}{c}\text { Kognitif } \\
\text { Rendah }\end{array}$ & 33.4 & 3.20 & 50.6 & 4.56 & 17.2 & 1.36 \\
\hline
\end{tabular}

Keterangan:

$\ddot{X}$ : Rata-rata skor keterampilan

Sd : Standar deviasi

\section{Uji Normalitas}

Pengujian persyaratan analisis data adalah menguji normalitas data mengenai kelompok IQ tinggi dan rendah melalui metode pembelajaran langsung. Setelah dilakukan deskripsi data, maka selanjutnya adalah melakukan uji normalitas data. Uji normalitas yang digunakan dalam penelitian ini adalah uji Liliefors pada taraf signifikansi $\alpha=0.05$. Berikut ini adalah ringkasan hasil uji normalitas data selisih pretest-posttest hasil belajar keterampilan bola basket yang dapat dilihat pada Tabel 2.

Tabel 2

Hasil Uji Normalitas Selisih Data Pretest dan Posttest Pembelajaran Bolabasket

\begin{tabular}{lcccc}
\hline Kelompok & $\mathbf{N}$ & $\mathbf{L}_{\text {hitung }}$ & $\mathbf{L}_{\text {tabel }}$ & Keterangan \\
\hline $\begin{array}{l}\text { Kognitif } \\
\text { Tinggi }\end{array}$ & 10 & 0.103 & 0.220 & Normal \\
$\begin{array}{l}\text { Kognitif } \\
\text { Rendah }\end{array}$ & 10 & 0.190 & 0.220 & Normal \\
\hline
\end{tabular}


Berdasarkan tabel 2, terlihat bahwa harga Liliefors hitung pada seluruh kelompok data ternyata lebih kecil dari harga Liliefors tabel. Dengan demikian dapat disimpulkan bahwa sampel penelitian ini berasal dari populasi yang berdistribusi normal. Kesimpulan ini memberikan implikasi bahwa analisis statistika parametrik dapat digunakan untuk menguji hipotesis yang diajukan dalam penelitian ini, sehingga syarat pertama untuk pengujian hipotesis telah terpenuhi.

\section{Uji Homogenitas}

Uji homogenitas untuk masing-masing kelompok data keterampilan bola basket menggunakan uji Bartlett pada taraf signifikansi $\alpha=0.05$. Ringkasan hasil penghitungannya dapat dilihat pada Tabel 3.

Tabel 3

Ringkasan Hasil Variansi Kelompok Kognitif Tinggi dan Rendah

\begin{tabular}{cc}
\hline Kelompok & $\left.\mathbf{( S}^{\mathbf{2}}\right)$ \\
\hline Kognitif Tinggi & 16 \\
Kognitif Rendah & 5 \\
\hline
\end{tabular}

Selanjutnya membandingkan varians terbesar dan terkecil diantara kelompok kognitif tinggi dan kognitif rendah, masing-masing dari hasil selisih. Kemudian hasilnya dibandingkan dengan nilai dari tabel distribusi F.

Tabel 4

Hasil Penghitungan Uji Homogenitas

\begin{tabular}{cccc}
\hline $\begin{array}{c}\text { Kelompok yang } \\
\text { Diuji }\end{array}$ & $\mathbf{F}_{\text {hitung }}$ & $\mathbf{F}_{\text {tabel }}$ & Kesimpulan \\
\hline $\begin{array}{c}\text { Kognitif Tinggi } \\
\text { dan }\end{array}$ & 3.27 & 1.83 & $\begin{array}{c}\text { Tidak } \\
\text { Homogen }\end{array}$ \\
\begin{tabular}{c} 
Kognitif Rendah \\
\hline
\end{tabular} & & & \\
\hline
\end{tabular}

Berdasarkan hasil penghitungan, maka diperoleh bahwa nilai $\mathrm{F}$ hitung tes sebesar 3,27 dan $\mathrm{F}$ table pada taraf $\alpha=0.05$ dan derajat kebebasan (dk) pembilang $=\mathrm{n}-1=10-1=9$ dan derajat kebebasan penyebut $=\mathrm{n}-1=10-1=9$ atau nilai $\mathrm{F}$ tabel $=1,83$. Ternyata $F_{\text {hitung }}(3,27)$ lebih besar dari nilai yang ditunjukkan oleh tabel $\left(F_{\text {hitung }}>F_{\text {tabel }}\right)$, yakni F- hitung $(3,27)>F$ - tabel $(1,83)$. Dengan demikian, dapat disimpulkan hipotesis Ho diterima dan data bersifat tidak homogen.

\section{Pengujian Hipotesis}

Langkah selanjutnya adalah menguji kesamaan dua rata-rata (satu pihak). Hal ini dilakukan untuk mengetahui pengaruh antara siswa yang memiliki kognitif tinggi dengan siswa yang memiliki kognitif rendah terhadap hasil pembelajaran langsung bolabasket. Hasil penghitungan uji signifikansi kelompok kognitif tinggi dan rendah pada pembelajaran bolabasket, dapat dilihat pada tabel 5. 
Tabel 5

Hasil Penghitungan Uji Kesamaan Dua Rata-rata (Satu Pihak) Kelompok Kognitif Tinggi dan Kognitif Rendah

\begin{tabular}{cccc}
\hline Kelompok & $\mathbf{T}_{\text {hitung }}$ & $\mathbf{T}_{\text {tabel }}$ & Kesimpulan \\
\hline $\begin{array}{c}\text { Kognitif Tinggi } \\
\text { dan Kognitif } \\
\text { Rendah }\end{array}$ & 2.54 & 1.70 & Signifikan \\
\hline
\end{tabular}

\section{PEMBAHASAN}

Berdasarkan hasil penghitungan di atas didapat $\mathrm{T}_{\text {hitung dari kelompok }}$ kognitif tinggi dan kognitif rendah pada pembelajaran bolabasket adalah 2,54, sedangkan $\mathrm{T}_{\text {tabel }}$ dengan peluang 0,95 dan $\mathrm{dk}=9$ di dapat 1,70. Hal ini menunjukkan nilai $\mathrm{T}_{\text {hitung }}$ dari kelompok kognitif tinggi dan kognitif rendah lebih besar dari $\mathrm{T}_{\text {tabel }}$ atau berada di luar daerah penerimaan Ho, dan ini berarti adanya perbedaan pengaruh pembelajaran bola basket dari kedua kelompok tersebut yang berarti dapat disimpulkan bahwa terdapat perbedaan pengaruh kemampuan kognitif tinggi dengan kognitif rendah terhadap hasil pembelajaran bolabasket dalam pendidikan jasmani.

Berdasarkan deskripsi hasil analisis data, pada dasarnya kelompok siswa yang memiliki tingkat kognitif tinggi dan rendah menunjukkan peningkatan yang signifikan di dalam hasil pembelajaran keterampilan bolabasket melalui pengajaran metode langsung. Tujuan utama metode pembelajaran ini adalah untuk memaksimalkan penggunaan waktu belajar siswa. Beberapa temuan dalam teori perilaku diantaranya adalah pencapaian siswa yang dihubungkan dengan waktu yang digunakan oleh siswa dalam belajar atau tugas akan menghasilkan kecepatan keberhasilan siswa dalam mengerjakan tugas sangat positif. Dengan kata lain, metode pembelajaran langsung dirancang untuk menciptakan lingkungan belajar yang terstruktur dan berorientasi pada pencapaian akademik. Sejalan dengan yang disampaikan oleh Garten, Taylor dan Graves (Juliantine, 2011) bahwa metode pembelajaran langsung sangat cocok jika guru menginginkan siswa menguasai informasi atau keterampilan tertentu.

Selain itu, hasil penelitian ini menunjukkan bahwa terdapat perbedaan pengaruh yang cukup signifikan antara kelompok siswa yang memiliki kognitif tinggi dan rendah terhadap hasil pembelajaran langsung bolabasket. Temuan di lapangan bahwa kelompok siswa yang memiliki kemampuan kognitif tinggi didalam proses pembelajaran perkembangannya terlihat lebih cepat dibandingkan dengan kelompok siswa yang memiliki kemampuan kognitif rendah. Sejalan dengan yang disampaikan Paulina (1997) bahwa faktor seperti kognitif yang berasal dari diri siswa, (strategi kognitif) dapat secara signifikan berpengaruh pada kemampuan pembelajaran dan kualitas hasil pembelajaran dalam pendidikan jasmani. Artinya siswa yang memiliki kemampuan kognitif tinggi cenderung akan lebih optimal di dalam proses pembelajaran yang ikutinya. 


\section{SIMPULAN}

Berdasarkan hasil pengolahan data dan analisis data yang telah dilakukan, maka dapat diambil kesimpulan sebagai berikut: Terdapat pengaruh yang signifikan siawa yang memiliki kemampuan kognitif tinggi terhadap hasil pembelajaran bola basket. Terdapat pengaruh yang signifikan siswa yang memiliki kemampuan kognitif rendah terhadap hasil pembelajaran bolabasket. Terdapat perbedaan pengaruh yang signifikan antara siswa yang memiliki kemampuan kognitif tinggi dengan kemampuan kognitif rendah terhadap hasil pembelajaran bolabasket, bahwa pengaruh kemampuan kognitif tinggi lebih baik dari pada kemampuan kognitif rendah.

\section{DAFTAR PUSTAKA}

Darsinah. (2011). Perkembangan Kognitif. Qinant. Solo Baru.

Darsono. (2001). Belajar dan Pembelajaran. IKIP Semarang Press. Semarang.

Freeman. (1962). Theory and Practice of Psychological Testing. Third edition. Oxford \& IBH Publishing. New Delhi.

Hariwijaya, M. (2005). Tes Intelegensi Cara Akurat Mengukur Kecerdasan Intelektual Anda. Yogyakarta: Andi Offset.

Juliantine. (2011). Model-model Pembelajaran Pendidikan Jasmani. FPOK UPI. Bandung.

Nurhasan. (1999). Tes dan Pengukuran dalam Pendidikan Jasmani. Depdiknas. Jakarta.

Paulina. (1997). Strategi Kognitif. Direktorat Jendral Pendidikan Tinggi Departemen Pendidikan Nasional. Jakarta.

Prasetyono, S.,D. (2011). Buku Besar Aneka Psikotes. DIVA Press.

Sagala, S. (2005). Konsep dan Makna Pembelajaran. Alfabeta. Bandung.

Sodikun, (1991). Olahraga Pilihan Bola Basket. Depdikbud Dirjen Dikti Proyek Pembinaan Tenaga Kependudukan. Jakarta.

Suciati. (2007). Belajar dan Pembelajaran. Universitas Terbuka. Jakarta.

Sucipto. (2010). Permainan Bola basket. FPOK UPI. Bandung.

Sujiono. (2010). Metode Pengembangan Kognitif. Universitas Terbuka. Jakarta.

Sugiyono. (2010). Metode Penelitian Kuantitatif Kualitatif dan R\&D. Alfabeta.

Bandung. 